\title{
Extensive clinical, hormonal and genetic screening in a large consecutive series of $46, X Y$ neonates and infants with atypical sexual development
}

Dorien Baetens ${ }^{1}$, Wilhelm Mladenov ${ }^{2,3}$, Barbara Delle Chiaie ${ }^{1}$, Björn Menten ${ }^{1}$, An Desloovere ${ }^{2}$, Violeta lotova ${ }^{3}$, Bert Callewaert ${ }^{1}$, Erik Van Laecke ${ }^{4}$, Piet Hoebeke ${ }^{4}$, Elfride De Baere ${ }^{1}$ and Martine Cools ${ }^{2 *}$

\begin{abstract}
Background: One in 4500 children is born with ambiguous genitalia, milder phenotypes occur in one in 300 newborns. Conventional time-consuming hormonal and genetic work-up provides a genetic diagnosis in around $20-40 \%$ of $46, X Y$ cases with ambiguous genitalia. All others remain without a definitive diagnosis. The investigation of milder cases, as suggested by recent reports remains controversial.

Methods: Integrated clinical, hormonal and genetic screening was performed in a sequential series of $46, X Y$ children, sex-assigned male, who were referred to our pediatric endocrine service for atypical genitalia (2007-2013).

Results: A consecutive cohort of undervirilized 46,XY children with external masculinization score (EMS) 2-12, was extensively investigated. In four patients, a clinical diagnosis of Kallmann syndrome or Mowat-Wilson syndrome was made and genetically supported in $2 / 3$ and $1 / 1$ cases respectively. Hormonal data were suggestive of a (dihydro) testosterone biosynthesis disorder in four cases, however no HSD17B3 or SRD5A2 mutations were found. Array-CGH revealed a causal structural variation in 2/6 syndromic patients. In addition, three novel NR5A1 mutations were found in non-syndromic patients. Interestingly, one mutation was present in a fertile male, underlining the inter- and intrafamilial phenotypic variability of NR5A1-associated phenotypes. No AR, SRY or WT1 mutations were identified.

Conclusion: Overall, a genetic diagnosis could be established in 19\% of non-syndromic and 33\% of syndromic cases. There is no difference in diagnostic yield between patients with more or less pronounced phenotypes, as expressed by the external masculinisation score (EMS). The clinical utility of array-CGH is high in syndromic cases. Finally, a sequential gene-by-gene approach is time-consuming, expensive and inefficient. Given the low yield and high expense of Sanger sequencing, we anticipate that massively parallel sequencing of gene panels and whole exome sequencing hold promise for genetic diagnosis of 46,XY DSD boys with an undervirilized phenotype.
\end{abstract}

Keywords: 46,XY DSD, Undervirilization, Integrated screening, Diagnosis, Array-CGH, MLPA, NR5A1 mutations

\footnotetext{
* Correspondence: martine.cools@ugent.be

${ }^{2}$ Department of Pediatric Endocrinology, Ghent University Hospital and Ghent University, Building 3K12D, De Pintelaan 185, 9000 Ghent, Belgium Full list of author information is available at the end of the article
} 


\section{Background}

The birth of a child with ambiguous genitalia is a rare event with a prevalence of one in 4500 live births and poses a challenge to the parents and the medical team [1]. Specialized multidisciplinary medical care, aiming at addressing concerns and uncertainties with regard to gender assignment, underlying etiology and management, as well as providing adequate psychological support is essential [2]. Extensive and time-consuming hormonal and genetic work-up provides a genetic diagnosis in $20-40 \%$ of cases $[3,4]$. Less pronounced atypical development of male external genitalia is more prevalent and is noticed in the newborn period in around one in 300 males; $75 \%$ of cases are associated with hypospadias [5]. These milder forms of undervirilization, such as isolated or combined cryptorchidism and hypospadias have been related to environmental factors, low birth weight and multiple gene polymorphisms rather than single gene mutations [6-8]. However, mutations in the Androgen Receptor (AR), Nuclear Receptor Subfamily 5 Group A Member 1 (NR5A1) and Wilms Tumor 1 (WT1) genes - classically associated with genital ambiguity or more severe forms of undervirilization - have recently been identified in cases with isolated proximal or even distal hypospadias, combined cryptorchidism and (distal) hypospadias or anorchia, and sequencing of these genes has been advocated in such cases [9-14]. On the other hand, copy number variations in genes involved in the process of sexual development have effectively been detected by whole genome (array comparative genomic hybridization, array-CGH) or targeted (multiplex ligation-dependent probe amplification, MLPA) copy number analysis [15-17], and both techniques have become widely available in recent years. However, whether a systematic extensive genetic work-up is indicated in the 46,XY newborn with a milder degree of undervirilization, as indicated by a higher Prader or External Masculinization Score (EMS) remains a matter of debate [18]. Current screening methods are time consuming and have a low efficiency. The introduction of genome-wide technologies such as whole exome sequencing (WES) holds promise for future clinical decision making in a routine diagnostic setting for these rare, genetically heterogeneous conditions.

In order to gain insight in the appropriateness and diagnostic yield of a systematic genetic work-up in 46, $\mathrm{XY}$ infants with atypical external genitalia, we performed a standardized genetic screening panel in all 46,XY neonates and infants who were referred to our pediatric endocrine service for atypical male or ambiguous genitalia in the period 2007-2013 and who received male sex assignment. This screening consisted of consecutive Sanger sequencing of the $A R, N R 5 A 1$ and WT1 genes, high-resolution $(180 \mathrm{~K})$ array- $\mathrm{CGH}$ and a commercially available MLPA kit with probes for Sex Determining
Region Y (SRY), SRY-box 9 (SOX9), Nuclear Receptor Subfamily 0 Group B Member 1 (NROB1), Wingless type 4 (WNT4) and NR5A1. Additionally, sequencing of SRY was performed in cases with hormonal results consistent with the presence of (partial) gonadal dysgenesis, and sequencing of Hydroxysteroid (17-Beta) Dehydrogenase (HSD17B3) or Steroid-5-Alpha-Reductase, Alpha Polypeptide 2 (SRD5A2) was performed in cases with suspicion of a (dihydro)testosterone biosynthesis defect. Results were interpreted in the light of clinical and hormonal findings.

\section{Patients and methods \\ Patients}

All 46,XY children younger than two years who were referred to our pediatric endocrinology service for the evaluation of atypical genitalia (e.g. hypospadias, micropenis) and who were sex assigned male, between 2007-2013 were included $(\mathrm{n}=32)$ (Table 1$)$. Medical history included pregnancy details, birth weight (BW), consanguinity and a familial history of disorders of sex development (DSD), sub- or infertility, premature ovarian failure (POF) or atypical genitalia. Phenotypic description consisted of a physical examination with special attention to dysmorphism; EMS scores were calculated based on the aspect of the external genitalia [19]. None of the patients had proteinuria or renal insufficiency.

\section{Methods}

\section{Biochemical analyses}

Hormonal levels were obtained between day 14-90 after birth or after HCG stimulation (Pregnyl ${ }^{\circ}$, 1500U, with blood sampling at baseline and after 72 hours). The following hormone levels were measured: anti-Müllerian Hormone (AMH) by enzyme linked immunosorbent assay (Beckman Coulter Company), Androstenedione (A) by Radioimmunoassay (DiaSource Company), Testosterone (T) and Dihydrotestosterone (DHT) by liquid chromatography/tandem mass spectrometry (UPLC Waters quattro premier). LH and FSH by electrochemoluminescence assay (Roche Diagnostics E170 Modular).

\section{Genetic analyses}

Array-CGH using the Agilent $180 \mathrm{~K}$ array was used as a genomewide screen for copy number variations (CNVs) with an overall mean probe spacing of $14 \mathrm{~kb}$, or $11 \mathrm{~kb}$ when only taking into account the Refseq genes. Hybridization was done according to the manufacturer's protocol, followed by visualization of the results in arrayCGHbase [20]. Fluorescent in situ hybridization (FISH) was performed for $S R Y$ to search for $S R Y$ rearranging translocations and mosaicism. To screen for CNVs on the exon level, MLPA was done using the SALSA MLPA P185 Intersex probemix (MRC-Holland) containing probes for NROB1, NR5A1, SOX9, SRY and WNT4. Sanger sequencing of the 
Table 1 Medical history and phenotypic details of patients

\begin{tabular}{|c|c|c|c|c|c|c|c|c|}
\hline Code & $\begin{array}{l}\text { GA } \\
\text { (weeks) }\end{array}$ & BW (g) & $\begin{array}{l}\text { BW } \\
\text { (SD) }\end{array}$ & EMS & Pregnancy & $\begin{array}{l}\text { Dysmorphic } \\
\text { features }\end{array}$ & Consanguinity & Family history \\
\hline 1 & 32 & 900 & -3.15 & $2 / 12$ & CS & IUGR & No & Unremarkable \\
\hline \multirow[t]{3}{*}{2} & 41 & 3.260 & -1.12 & $3 / 12$ & Normal & Large ears & No & Unremarkable \\
\hline & & & & & & Broad nose & & \\
\hline & & & & & & $\begin{array}{l}\text { Mild frontal } \\
\text { bossing }\end{array}$ & & \\
\hline 3 & 40 & 4.150 & 1.12 & $\begin{array}{l}2,5 / \\
12\end{array}$ & Normal & / & No & $\begin{array}{l}\text { Maternal aunt: difficulties to get } \\
\text { pregnant, one child with congenital } \\
\text { abnormalities }\end{array}$ \\
\hline \multirow[t]{2}{*}{4} & 41 & 3.060 & -1.6 & $3 / 12$ & Normal & / & No & Unremarkable \\
\hline & & & & & $\begin{array}{l}\text { Minoxidil } \\
\text { treatment }\end{array}$ & & & \\
\hline 5 & 34 & 1.320 & -2.93 & $\begin{array}{l}7,5 / \\
12\end{array}$ & CS & IUGR & No & Unremarkable \\
\hline 6 & 40 & 3.380 & -0.59 & $9 / 12$ & Normal & / & No & $\begin{array}{l}\text { Grandfather with hypospadias, maternal } \\
\text { aunt with POF }\end{array}$ \\
\hline \multirow[t]{2}{*}{7} & 30 & 510 & -3.8 & $6 / 12$ & Induced delivery & IUGR & No & Paternal grandmother: cleft lip \\
\hline & & & & & Twins & & & \\
\hline 8 & 39 & 3.690 & 0.45 & $\begin{array}{l}10 / \\
12\end{array}$ & IVF & / & No & Unremarkable \\
\hline 9 & 38 & 3.310 & 0.01 & $8 / 12$ & Normal & / & No & Unremarkable \\
\hline \multirow[t]{2}{*}{10} & 39 & 2.850 & -1.53 & $9 / 12$ & Placental infarction & Microcephaly & No & Unremarkable \\
\hline & & & & & & $\begin{array}{l}\text { Mild facial } \\
\text { dysmorphism }\end{array}$ & & \\
\hline \multirow[t]{4}{*}{11} & 40 & 3.000 & -1.51 & $3 / 12$ & Normal & Macrocephaly & No & Unremarkable \\
\hline & & & & & & $\begin{array}{l}\text { Facial } \\
\text { dysmorphism }\end{array}$ & & \\
\hline & & & & & & Short neck & & \\
\hline & & & & & & $\begin{array}{l}\text { Developmental } \\
\text { delay (speech) }\end{array}$ & & \\
\hline 12 & 40 & 3.850 & 0.47 & $6 / 12$ & Normal & / & Yes & $\begin{array}{l}\text { Mother: fertility problems, irregular } \\
\text { menses }\end{array}$ \\
\hline \multirow[t]{4}{*}{13} & 35 & 2.530 & -0.26 & $6 / 12$ & $\begin{array}{l}\text { Preeclampsia and } \\
\text { hypertension }\end{array}$ & / & No & Unremarkable \\
\hline & & & & & Obesity & & & \\
\hline & & & & & Twins & & & \\
\hline & & & & & Sectio & & & \\
\hline \multirow[t]{2}{*}{14} & 32 & 945 & -2.98 & $3 / 12$ & Bleeding & / & No & Unremarkable \\
\hline & & & & & CS & & & \\
\hline 15 & 40 & NA & NA & $3 / 12$ & Normal & / & No & Unremarkable \\
\hline \multirow[t]{2}{*}{16} & 28 & 860 & -1.26 & $7 / 12$ & Eclampsy & Atrial septum & No & Unremarkable \\
\hline & & & & & Prematurity & & & \\
\hline 17 & 34 & 1.450 & -2.52 & $6 / 12$ & $\mathrm{CS}$ & $\begin{array}{l}\text { Ventricular septum } \\
\text { defect }\end{array}$ & Yes & Cousin (deceased)with Jeune syndrome \\
\hline \multirow[t]{2}{*}{18} & 34 & 1.400 & -2.68 & $2 / 12$ & CS & / & No & Unremarkable \\
\hline & & & & & $\begin{array}{l}\text { Antidepressant } \\
\text { Paroxetine }\end{array}$ & & & \\
\hline 19 & 41 & 2.805 & -2.24 & $3 / 12$ & Normal & / & No & Unremarkable \\
\hline 20 & 39 & 2.880 & -1.45 & $6 / 12$ & Normal & / & Possible & Unremarkable \\
\hline
\end{tabular}


Table 1 Medical history and phenotypic details of patients (Continued)

\begin{tabular}{|c|c|c|c|c|c|c|c|c|}
\hline 21 & 36 & 1.585 & -3.39 & $7 / 12$ & Preeclampsia & / & No & Unremarkable \\
\hline 22 & 39 & 2.640 & -2.07 & $6 / 12$ & Normal & / & No & Unremarkable \\
\hline 23 & 40 & 3.250 & -0.9 & $8 / 12$ & Normal & / & No & Unremarkable \\
\hline 24 & 37 & 3.290 & -0.43 & $6 / 12$ & Normal & / & Yes & Unremarkable \\
\hline \multirow[t]{5}{*}{25} & 38 & 2.800 & -1.20 & $6 / 12$ & Preeclampsia & / & No & Mother: brother deceased from SIDS \\
\hline & & & & & & & & Maternal grandfather: depression \\
\hline & & & & & & & & $\begin{array}{l}\text { Maternal grandmother: recurrent } \\
\text { miscarriage }\end{array}$ \\
\hline & & & & & & & & Father: late puberty \\
\hline & & & & & & & & $\begin{array}{l}\text { Paternal uncle: retractile testes, } \\
\text { normal fertility }\end{array}$ \\
\hline 26 & 39 & 3.770 & -0.63 & $\begin{array}{l}12 / \\
12\end{array}$ & Preterm contractions & $\begin{array}{l}\text { Hypoplastic bulbus } \\
\text { olfactorius }\end{array}$ & / & Unremarkable \\
\hline \multirow[t]{3}{*}{27} & 26 & 700 & -1.26 & $10 /$ & IVF & Persisting & / & Unremarkable \\
\hline & & & & 12 & Twins & & & \\
\hline & & & & & Placental rupture & $\begin{array}{l}\text { Periventricular } \\
\text { leukcomalacy }\end{array}$ & & \\
\hline \multirow[t]{4}{*}{28} & 36 & 2.570 & -0.72 & $8 / 12$ & Previous abortions & X-linked ichthyosis & / & First child was stillborn \\
\hline & & & & & \multirow[t]{2}{*}{ Preterm contractions } & Hypotonia & & \multirow{3}{*}{$\begin{array}{l}\text { Three miscarriages between } \\
\text { month } 1 \text { and } 2\end{array}$} \\
\hline & & & & & & $\begin{array}{l}\text { Developmental } \\
\text { delay ductus } \\
\text { arteriosus }\end{array}$ & & \\
\hline & & & & & Bleeding & $\begin{array}{l}\text { Abnormal liver } \\
\text { function tests }\end{array}$ & & \\
\hline 29 & 39 & 3.230 & $-0,6$ & $9 / 12$ & $\begin{array}{l}\text { Pregnancy after } \\
\text { gonadotrophin } \\
\text { treatment father }\end{array}$ & / & / & $\begin{array}{l}\text { Father with Kallmann syndrome, } \\
\text { pregnancy after gonadotrophins }\end{array}$ \\
\hline 30 & 38 & 3.782 & 1.04 & $8 / 12$ & Normal & $\begin{array}{l}\text { Mowat-Wilson } \\
\text { syndrome }\end{array}$ & / & Unremarkable \\
\hline 32 & 39 & 2780 & -1.70 & $7 / 12$ & Normal & No & No & Unremarkable \\
\hline
\end{tabular}

GA: gestational age, BW: birth weight, EMS: external masculinization score, IUGR: intra uterine growth retardation, POF: premature ovarian failure, SIDS: sudden infant death syndrome; CS: Caesarian section, IVF: in vitro fertilization.

coding exons and untranslated regions (UTRs) was used to identify mutations in AR, NR5A1 and WT1. SRY sequencing was included for patients suspected to have gonadal dysgenesis, based on an $A M H$ level below the reference range. $H S D 17 B 3$ and $S R D 5 A 2$ were sequenced in cases with suspicion of a testosterone biosynthesis disorder based on a T/A ratio $<1$ for $17 \beta$-HSD deficiency and a T/DHT ratio $>8.5$ for $5 \alpha$ Reductase Deficiency (Table 2) $[21,22]$. Primers for $A R, W T 1$ en $S R Y$ were designed using PrimerXL (http://www.primerxl.org/, available on request). Primer sequences for NR5A1, HSD17B3 and SRD5A2 can be found in supplemental data (Additional file 1: Table S1). Zinc Finger E-Box Binding Homeobox 2 (ZEB2) sequencing and sequencing of the Kallmann syndrome (KS) gene panel, consisting of six genes (KAL1, CHD7, FGFR1, PROK2, PROKR2, FGF8) was done at the Henri Mondor Hospital (Paris, France). Fibroblast Growth Factor Receptor 1 (FGFR1) sequencing was performed at the CHU Hospital Cochin (Paris, France).

\section{Cell culture, RNA extraction and CDNA synthesis}

Lymphocytes were isolated by Lymphoprep $^{\text {TM }}$ (STEMCELL Technologies) and cultured in RPMI medium with 10\% FCS; interleukin-2 and phytohemagglutin were added. Cells were incubated at $37^{\circ} \mathrm{C}$ and $5 \% \mathrm{CO}_{2}$. RNA was extracted using the RNeasy Plus Mini kit (Qiagen), followed by cDNA synthesis with the iScript ${ }^{\mathrm{TM}} \mathrm{cDNA}$ synthesis kit (Biorad).

\section{Expression analysis}

Expression levels of NR5A1 were measured through real-time quantitative PCR (rt-qPCR), using following primers: NR5A1-F 5' caggagtttgtctgcctcaa $3^{\prime}$ and NR 5A1-R 5' agtggcacagggtgtagtca $3{ }^{\prime}$. After in silico validation primers were tested using a dilution series. The experiment was done with the SsoAdvanced SYBR supermix (Bio-rad). Analysis of rt-qPCR results was done with qbase + software (Biogazelle). 
Table 2 Hormonal and genetic data of patients

\begin{tabular}{|c|c|c|c|c|c|c|c|c|c|c|}
\hline Code & $\begin{array}{l}\text { FSH } \\
(\mathrm{U} / \mathrm{I}) \# \text { (ref) }\end{array}$ & $\begin{array}{l}\text { AMH } \\
(\mu \mathrm{g} / \mathrm{l}) \\
(\mathrm{ref}) \$\end{array}$ & $\begin{array}{l}\mathrm{T} \\
(\mathrm{ng} / \mathrm{dl})^{*} / * *\end{array}$ & $A R$ & NR5A1 & WT1 & $S R Y$ & Array-CGH & MLPA & Other \\
\hline 1 & $3.2(1-12)$ & $\begin{array}{l}59.8(46.8- \\
173)\end{array}$ & $136^{*}$ & $\mathrm{Nl}$ & $\mathrm{Nl}$ & $\mathrm{Nl}$ & $\begin{array}{l}\mathrm{FISH} \\
\mathrm{NI}\end{array}$ & $\mathrm{NI}$ & $\mathrm{Nl}$ & HSD17B3 \\
\hline 2 & $14.0(1-12)$ & $\begin{array}{l}62.7(46.8- \\
173)\end{array}$ & $\begin{array}{l}63.8^{*} / \\
579^{* *}\end{array}$ & / & $\mathrm{Nl}$ & $\mathrm{Nl}$ & $\mathrm{NI}$ & $\mathrm{Nl}$ & $\mathrm{Nl}$ & $\begin{array}{l}\text { HSD17B3, } \\
\text { ATRX N }\end{array}$ \\
\hline 3 & $6.6(1-12)$ & $\begin{array}{l}10.8(105- \\
270)\end{array}$ & $4.7^{*}$ & / & c.253_254del & / & $\mathrm{NI}$ & / & / & \\
\hline 4 & $1.6(1-12)$ & $\begin{array}{l}118(46.8- \\
173)\end{array}$ & $195^{*}$ & $\mathrm{Nl}$ & $\mathrm{Nl}$ & $\mathrm{NI}$ & / & $\mathrm{NI}$ & $\mathrm{Nl}$ & \\
\hline 5 & NA & $\begin{array}{l}152(67.4- \\
197)\end{array}$ & $526^{* *}$ & $\mathrm{Nl}$ & $\begin{array}{l}\text { c. } 437 G>C \\
\text { (tolerated) }\end{array}$ & I & $\begin{array}{l}\mathrm{FISH} \\
\mathrm{NI}\end{array}$ & / & / & \\
\hline 6 & $3.3(1-12)$ & $\begin{array}{l}64.5(62- \\
130)\end{array}$ & $184^{*}$ & $\mathrm{Nl}$ & c.630_637del & / & $\begin{array}{l}\mathrm{FISH} \\
\mathrm{NI}\end{array}$ & / & $\mathrm{Nl}$ & \\
\hline 7 & $1.5(1-12)$ & $\begin{array}{l}57.6(105- \\
270)\end{array}$ & $222^{*}$ & $\mathrm{Nl}$ & $\mathrm{Nl}$ & $\mathrm{Nl}$ & / & 7q36.3q36.3 (158189154-158343770)×1, maternal & $\mathrm{Nl}$ & \\
\hline 8 & NA & $\begin{array}{l}10.6(38- \\
180)\end{array}$ & $275^{* *}$ & $\mathrm{Nl}$ & $\mathrm{Nl}$ & $\mathrm{NI}$ & $\mathrm{NI}$ & $\mathrm{NI}$ & $\mathrm{Nl}$ & \\
\hline 9 & NA & $\begin{array}{l}231(46.8- \\
173)\end{array}$ & NA & $\mathrm{Nl}$ & $\mathrm{Nl}$ & $\mathrm{NI}$ & / & Xp22.33p22.33 (839417-1179089)×3, maternal & $\mathrm{Nl}$ & \\
\hline 10 & NA & $\begin{array}{l}244(46.8- \\
173)\end{array}$ & NA & $\mathrm{Nl}$ & $\mathrm{Nl}$ & $\mathrm{Nl}$ & / & $\mathrm{Nl}$ & $\mathrm{Nl}$ & ATRX NI \\
\hline 11 & $5.5(1-12)$ & NA & $158^{*} / 511^{* *}$ & / & / & / & / & $\begin{array}{l}\text { 3p25(RP11-385A18 } \rightarrow \text { RP11-334 L22)×3, 9p24.3 } \\
(\text { RP11-48 M17 } \rightarrow \text { RP11-320E16)×1 }\end{array}$ & / & \\
\hline 12 & $2.5(1-12)$ & $\begin{array}{l}147(46 \\
8-173)\end{array}$ & $109^{*}$ & / & $\mathrm{Nl}$ & $\mathrm{NI}$ & / & / & $\mathrm{Nl}$ & \\
\hline 13 & NA & $\begin{array}{l}72.7(46.8- \\
173)\end{array}$ & $280^{*}$ & / & $\mathrm{Nl}$ & $\mathrm{Nl}$ & $\begin{array}{l}\mathrm{FISH} \\
\mathrm{NI}\end{array}$ & $\mathrm{Nl}$ & $\mathrm{Nl}$ & \\
\hline 14 & $1.2(1-12)$ & $\begin{array}{l}8.6(105- \\
270)\end{array}$ & $248^{*}$ & $\mathrm{NI}$ & / & / & / & / & / & \\
\hline 15 & NA & $\begin{array}{l}132.9(42- \\
185)\end{array}$ & NA & $\mathrm{Nl}$ & $\begin{array}{l}c .1109 \mathrm{G}>\mathrm{A} \\
\text { (p Cys370Tyr) }\end{array}$ & / & $\begin{array}{l}\mathrm{FISH} \\
\mathrm{NI}\end{array}$ & $\begin{array}{l}\text { 16p12.3p12.3 (18894303-19162153)×3, maternal } \\
\text { (normal variant) }\end{array}$ & / & \\
\hline 16 & $1.3(1-12)$ & $\begin{array}{l}298(67.4- \\
197)\end{array}$ & $337^{*}$ & $\mathrm{Nl}$ & $\mathrm{Nl}$ & $\mathrm{Nl}$ & $\begin{array}{l}\mathrm{FISH} \\
\mathrm{NI}\end{array}$ & Xq13.3q13.3 (74285912-75325119)×2, maternal & $\mathrm{Nl}$ & \\
\hline 17 & NA & $\begin{array}{l}72(38- \\
180)\end{array}$ & NA & / & $\mathrm{Nl}$ & $\mathrm{NI}$ & $\begin{array}{l}\mathrm{FISH} \\
\mathrm{Nl}\end{array}$ & / & $\mathrm{NI}$ & HSD17B3 \\
\hline 18 & $2.6(1-12)$ & $\begin{array}{l}82.2(23.8- \\
124)\end{array}$ & NA & $\mathrm{Nl}$ & $\mathrm{Nl}$ & $\mathrm{NI}$ & / & $\begin{array}{l}\text { 2p16.3p16.3 (5073244-50894316)x1; } \\
16 p 13.11 \mathrm{p} 13.11(15830681-16270149) \times 3\end{array}$ & $\mathrm{Nl}$ & \\
\hline 19 & 1.8 & $\begin{array}{l}49.1(23.8- \\
124)\end{array}$ & $\begin{array}{l}35.3^{*} / \\
390^{* *}\end{array}$ & $\mathrm{Nl}$ & $\mathrm{Nl}$ & $\mathrm{Nl}$ & $\begin{array}{l}\mathrm{FISH} \\
\mathrm{NI}\end{array}$ & Xq13.3q13.3(74380482-74567915)×2, maternal & $\mathrm{Nl}$ & \\
\hline 20 & $2.8(1-12)$ & $\begin{array}{l}\text { 194(105- } \\
270)\end{array}$ & $104^{*}$ & $\mathrm{NI}$ & $\mathrm{Nl}$ & $\mathrm{NI}$ & $\begin{array}{l}\mathrm{FISH} \\
\mathrm{NI}\end{array}$ & $\mathrm{Nl}$ & $\mathrm{Nl}$ & \\
\hline 21 & $1.9(1-12)$ & $\begin{array}{l}28.8(55.3- \\
187)\end{array}$ & NA & $\mathrm{Nl}$ & $\mathrm{Nl}$ & $\mathrm{Nl}$ & $\mathrm{Nl}$ & / & $\mathrm{Nl}$ & \\
\hline 22 & $2.1(1-12)$ & $\begin{array}{l}94.1(105- \\
270)\end{array}$ & $151^{*}$ & $\mathrm{NI}$ & $\mathrm{Nl}$ & $\mathrm{Nl}$ & $\mathrm{Nl}$ & $\begin{array}{l}\text { 5p14.3p14.3(21438696-21490654)×1, maternal, } \\
14 q 21.2 q 21.3(42908541-43293564) \times 3 \text {, maternal }\end{array}$ & $\mathrm{Nl}$ & \\
\hline 23 & NA & $\begin{array}{l}11.27 \\
(55.3-187)\end{array}$ & $404^{* *}$ & $\mathrm{Nl}$ & $\mathrm{Nl}$ & $\mathrm{Nl}$ & $\mathrm{Nl}$ & $\mathrm{Nl}$ & $\mathrm{Nl}$ & \\
\hline 24 & NA & $\begin{array}{l}43(105- \\
270)\end{array}$ & $152^{*} / 474^{* *}$ & / & $\mathrm{Nl}$ & $\mathrm{Nl}$ & $\mathrm{Nl}$ & $\mathrm{Nl}$ & $\mathrm{Nl}$ & SRD5A2 N \\
\hline 25 & $1.0(1-12)$ & $\begin{array}{l}\text { 156(105- } \\
270)\end{array}$ & $207.3^{*}$ & $\mathrm{Nl}$ & $\mathrm{NI}$ & $\mathrm{Nl}$ & / & $\mathrm{Nl}$ & $\mathrm{Nl}$ & \\
\hline 26 & $0.17(1-12)$ & & & / & / & / & / & $\mathrm{Nl}$ & / & \\
\hline
\end{tabular}


Table 2 Hormonal and genetic data of patients (Continued)

\begin{tabular}{|c|c|c|c|c|c|c|c|c|c|c|}
\hline & & $\begin{array}{l}65.9(105- \\
270)\end{array}$ & $\begin{array}{l}3.3^{*} / 90.8 \\
* *\end{array}$ & & & & & & & \\
\hline 27 & NA & $\begin{array}{l}245(55.3- \\
187)\end{array}$ & $951^{* *}$ & $\mathrm{NI}$ & $\mathrm{Nl}$ & $\mathrm{NI}$ & / & / & $\mathrm{NI}$ & \\
\hline 28 & NA & $\begin{array}{l}14.03 \\
(55.3-187)\end{array}$ & NA & / & / & / & / & Xp22.32p22.31(5405569-9222059)×0, maternal & / & \\
\hline 29 & $0.57(1-12)$ & NA & $3.2^{*}$ & / & / & / & / & / & / & $\begin{array}{l}\text { FGFR1 } \\
\text { C.1042G> } \\
\text { A }\end{array}$ \\
\hline 30 & $1.2(1-12)$ & $\begin{array}{l}\text { 159(105- } \\
270)\end{array}$ & $502 *$ & / & / & / & / & $\mathrm{NI}$ & / & $\begin{array}{l}\text { ZEB2 } \\
\text { c.2856 delG }\end{array}$ \\
\hline 32 & $11(1-12)$ & $\begin{array}{l}25(105- \\
270)\end{array}$ & 191.9* & $\mathrm{Nl}$ & $\mathrm{NI}$ & $\mathrm{NI}$ & $\mathrm{NI}$ & $\mathrm{NI}$ & $\mathrm{NI}$ & \\
\hline
\end{tabular}

Symbols and abbreviations: NA not available, FSH follicle stimulating hormone, $A M H$ anti-Müllerian hormone, ref age-specific reference value, $T$ testosterone, NI, normal.

\# Determined between day 14-90; \$: age-specific AMH reference values may differ according to the commercial kits that have been used during the course of the study; *Basal testosterone value between day 14-90/**: Testosterone value after HCG stimulation (1500 $\mathrm{U}$, blood sampling after $72 \mathrm{~h}$ ).

Genomic coordinates based on build hg18 (2006), except for patient 32, where build hg19 (2009) is used.

The study was approved by the local medical ethical committee (Registration number B670201110608) and all parents signed a written informed consent.

\section{Results}

\section{Clinical investigation}

Consanguinity was present or suspected in $4 / 32$ cases (12.5\%). Another four cases had a family history of subfertility or atypical genitalia. Nine children (28.1\%) were born small for gestational age (SGA), defined as a BW $<-2$ Standard Deviation (SD) for gestational age, with a mean $\mathrm{BW}$ of $-2.8 \mathrm{SD}$; mean BW of children born appropriate for GA was -0.36 SD. EMS scores ranged from $2 / 12$ to 12/12. In 6/32 children (18.7 \%) dysmorphic features were noticed. Patient details are represented in Table 1.

Three out of 32 patients (P26, P28, P29) were diagnosed with KS based on clinical and hormonal data (day 14-90). Patient 26 (EMS 12) was referred for an atypically looking short penis (with bilateral descended testes). At physical examination, stretched penis length (SPL) measured $30 \mathrm{~mm}$, but his penis was extremely thin and weak, reminiscent of agenesis of the corpora cavernosa, which was excluded by Magnetic Resonance Imaging (MRI) of the penile structures. Hormonal data concordant with hypogonadotropic hypogonadism $(\mathrm{HoH})$ (Table 2) and MRI revealing a hypoplastic bulbus olfactorius were both consistent with a diagnosis of Kallmann syndrome. An etiological diagnosis was sought by targeted resequencing of several known KS genes (KAL1, FGFR1, FGF8, CHD7, PROK2, PROKR2, HS6ST1, WDR11, SEMA3A, GNRH1, GNRHR, KISS1, KISS1R, TAC3 and TACR3); no causal mutations were identified. The second patient with KS (P28, EMS 8) presented with mild craniofacial dysmorphism (ptosis, plagiocephaly), general hypotonia, developmental delay, micropenis (SPL $15 \mathrm{~mm}$ ) and bilateral inguinal testes. Low gonadotrophins in association with a low AMH was suggestive of $\mathrm{HoH}$. Array-CGH revealed a causal hemizygous deletion on the $\mathrm{X}$ chromosome including the Kallmann syndrome 1 (KAL1) gene, as discussed below. Patient 29 (EMS 9) was diagnosed with KS based on the presence of micropenis (SPL $21 \mathrm{~mm}$ ) and a positive family history for KS: the father had been diagnosed with $\mathrm{KS}$ and was able to conceive following gonadotrophin therapy. Hormonal data confirmed $\mathrm{HoH}$ in the index patient. The diagnosis was supported genetically by the identification of a heterozygous FGFR1 mutation, c.1042G > A (p.G348R), in both the patient and his father. This mutation has been described previously [23].

Patient 30 was diagnosed with Mowat-Wilson syndrome (MWS), he presented with typical external ear abnormalities (Figure 1), hypotonia, persistent ductus arteriosus, ventricular septum defect, facial dysmorphism, Hirschsprung disease, penoscrotal inversion and hypospadias. MWS is caused by heterozygous de novo mutations in $Z E B 2$. Sequencing of this gene revealed a heterozygous one basepair frameshift deletion, c. 2856delG (p.Arg953Glufs"24).

\section{Hormonal work-up}

With the exception of cases with KS, where FSH was low, serum FSH was within the reference range in all cases. AMH, representing Sertoli cell function, was low in $11 / 32$ cases $(34,3 \%$ ), including $2 / 3$ cases with KS (in the third KS case, AMH could not be determined) and 4/9 cases (44\%) born SGA. Low AMH was associated with low $\mathrm{T}$ values (a marker for Leydig cell function) in only two cases (P3, subsequently diagnosed with a NR5A1 mutation and P26, with KS). Two of three patients with NR5A1 mutations had an AMH value within the reference for age. Ratios of T/A and T/DHT were determined to identify possible cases of (dihydro)testosterone biosynthesis disorders. The T/A ratio, measured 


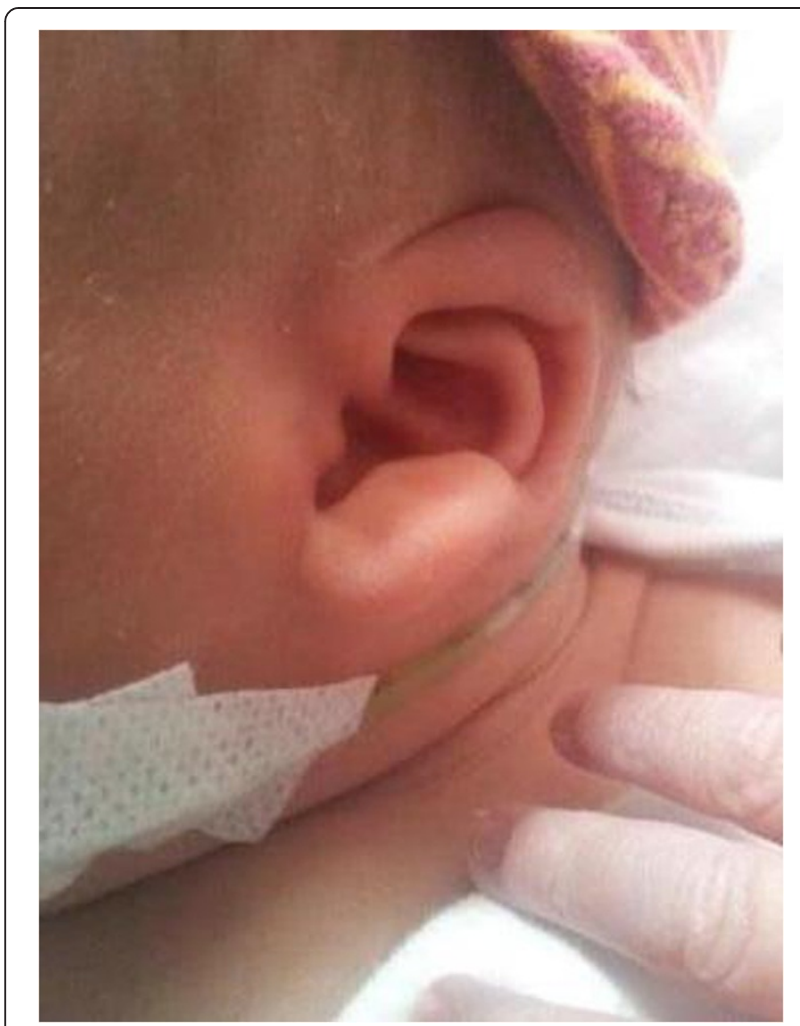

Figure 1 Mowat-Wilson syndrome, facial characteristics. The typical large and uplifted earlobes in Patient 30, who was diagnosed with Mowat-Wilson syndrome based on clinical data.

during mini-puberty was suggestive of $17 \beta$-HSD deficiency in two patients (case 1: T/A ratio 0,19; case 2: $\mathrm{T} /$ A ratio 0,52 ) and after HCG stimulation in one case (case 17: T/A ratio 0,08) [21,22]. HSD17B3 sequencing was performed in all three cases but revealed no causal mutations. In patient 2 a heterozygous missense variant was identified, c. 866G > A (p.Gly289Asp), although mutation prediction programs indicated this variant to be tolerated. In patient 24, a T/DHT ratio of 10,8 was found at basal sampling during mini-puberty but SRDSA2 sequencing revealed no mutations.

\section{Genetic work-up}

Array-CGH was done in 23/32 patients to screen for larger genomic rearrangements. In 10 of them, CNVs were identified as shown in Table 2. Seven of these rearrangements were maternally inherited, making their clinical significance questionable. In patient 11, we identified a partial chromosome 9 deletion (9p24.3), encompassing the Doublesex and Mab3 related transcription factor 1 (DMRT1) gene. In patient 28, a deletion was found on the X chromosome (Xp22.31-Xp22.32). This region includes the STS region and the genes KAL1 and Neuroligin 4, X-linked (NLGN4X). This deletion was also present in the patient's mother. In addition, we performed MLPA for 23/32 patients to screen for deletions and/or duplications on the exon level, however no additional CNVs were identified.

$A R(20 / 32)$ and WT1 (22/32) sequencing did not reveal any mutations. NR5A1 sequencing was done in 26/ 32 patients, leading to the identification of three novel mutations, which will be discussed below. In cases with serum AMH below the reference value for age (8/32), suggestive of gonadal dysgenesis, $S R Y$ was sequenced, however no mutations were found.

\section{Identification of three novel NR5A1 mutations}

NR5A1 sequencing revealed three novel mutations (Figure 2A). In patient 3 a heterozygous frameshift deletion was identified: c.253_254del, resulting in a premature stopcodon (p.Ala85*). No other family members were available for segregation analysis. A second heterozygous frameshift deletion of $8 \mathrm{bp}$ was identified in patient 6, c.630_637del, (p.Tyr211Profs*12). Rt-qPCR in the patient's lymphoblasts indeed showed a lower expression of NR5A1 mRNA (Figure 2B). Segregation analysis indicated that this mutation was present in (1) the asymptomatic patient's mother, (2) maternal aunt, who had been diagnosed with POF at the age of 35, and (3) grandfather, who had been operated for proximal hypospadias, but spontaneously fathered two children (pedigrees in Figure $2 \mathrm{C}$ ). The third mutation was found in patient 15, c.1109 G>A, (p.Cys370Trp). This mutation was predicted to have a deleterious effect on protein function according to several prediction programs (SIFT, Polyphen and MutationTaster). The affected amino acid is located in the ligand-binding domain and is highly conserved (up to zebrafish). Segregation analysis revealed that the mutation was present in the patient's mother, who had no symptoms of POF at the age of 24 .

\section{Discussion}

To gain insight into the appropriateness and diagnostic yield of a systematic integrated work-up in $46, \mathrm{XY}$ undervirilized cases who are sex-assigned male, we used a standardized screening panel in a series of 32 cases referred to our DSD clinic. An overview of the approach is shown in Figure 3A. Difficulties in blood collection in newborns and infants made it impossible to perform the complete screening in every case, resulting in missing data. Low EMS scores (EMS $<7, \mathrm{n}=17$ ) did not yield a higher diagnostic success as compared to higher EMS scores (EMS $\geq 7, n=15$ ). As reported earlier, no causal genetic variations were identified in children born SGA $(n=9)$ in our series [24].

\section{Clinical investigation and hormonal data were sufficient to diagnose Kallmann syndrome and Mowat-Wilson syndrome in respectively three and one patients} Familial, hormonal and/or phenotypic data were sufficient to suspect KS in three patients (P26, 28 and 29) and MWS 


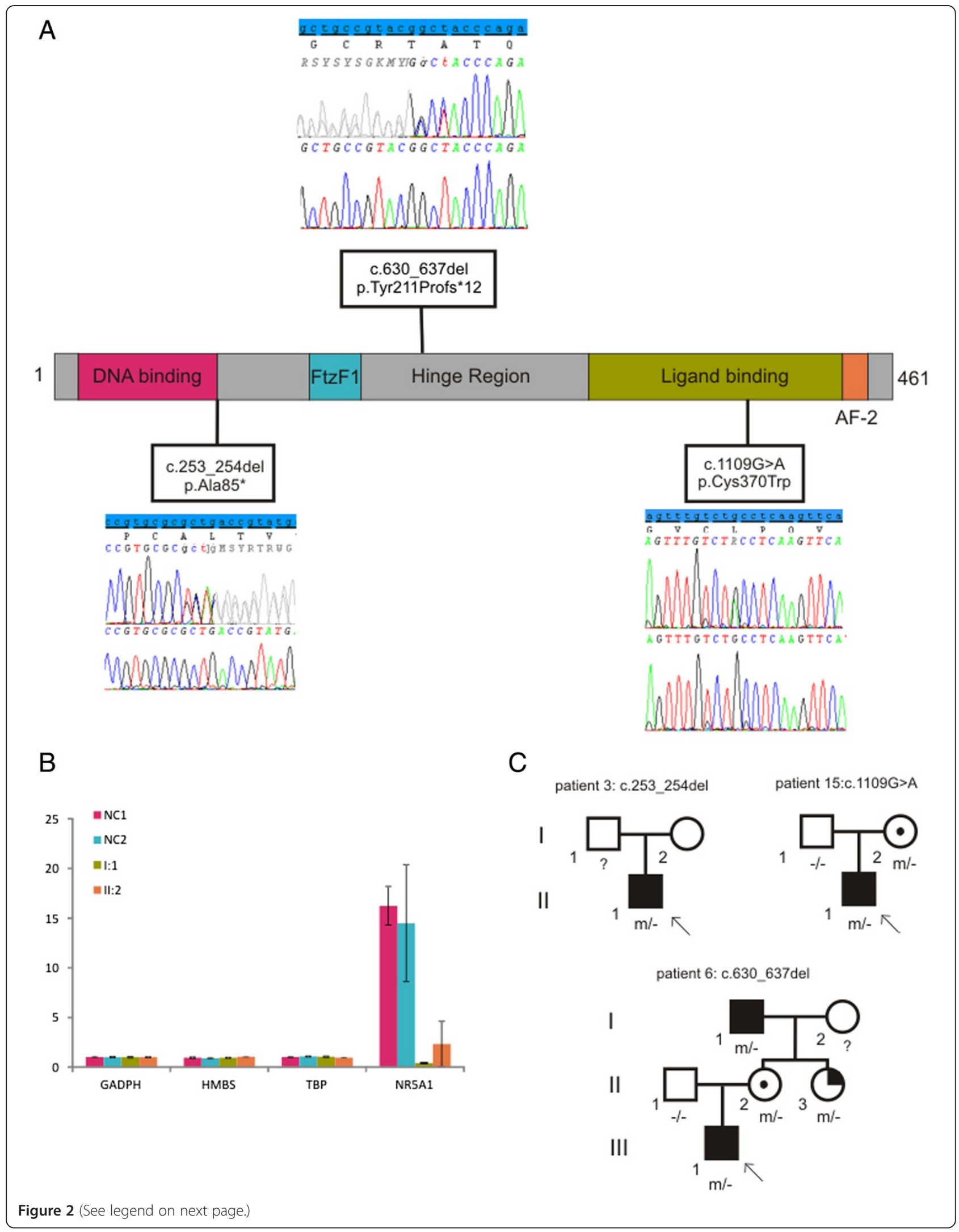


(See figure on previous page.)

Figure 2 Three novel NR5A1 mutations. (A) Schematic overview of the positions of the mutations and electropherograms. (B) RT-qPCR showed a lower NR5A1 expression in the maternal grandfather of the index patient (I:1), and in the mother of the index patient (II:2). We did not include the index case in this experiment as no fresh blood could be collected. Two negative control samples (NC) without the mutation were included for comparison. To exclude technical variations, expression of the reference genes GADPH, HMBS and TBP were also measured, showing stable expression in all patients. (C) Pedigrees for the patients with a NR5A7 mutation. The genotype of the analysed individuals is shown under their symbol. Full black squares indicate affected males with hypospadias, partially black circles indicate females with POF and circles with a black dot correspond with asymptomatic carrier females.

in patient 30. As suggested in a paper by Grumbach et al. our study confirms that in boys, the period of physiological gonadotrophin surge (the so-called "mini-puberty") represents a unique opportunity to diagnose KS early in cases with a suggestive phenotype (micropenis +/- cryptorchidism in the absence of hypospadias) [25]. In these patients a targeted approach to identify the underlying molecular cause was used. Here, we ended up with a higher diagnostic success rate, the molecular cause was identified in $75 \%(3 / 4)$ of patients.

\section{Despite suggestive hormonal results, we could not identify any HSD17B3, SRD5A2 or SRY mutations}

Accumulation of A or T due to $17 \beta-H S D$ deficiency or $5 \alpha$-reductase deficiency respectively may lead to markedly low T/A (in case of 17 $\beta$-HSD deficiency) or elevated T/DHT (in case of $5 \alpha$-reductase deficiency) ratios. In contrast to previous reports, sequencing of the HSD17B3 and SRD5A2 genes in cases with aberrant T/A and T/DHT ratios respectively revealed no mutations $[21,22,26,27]$. However, for practical reasons, stimulated A
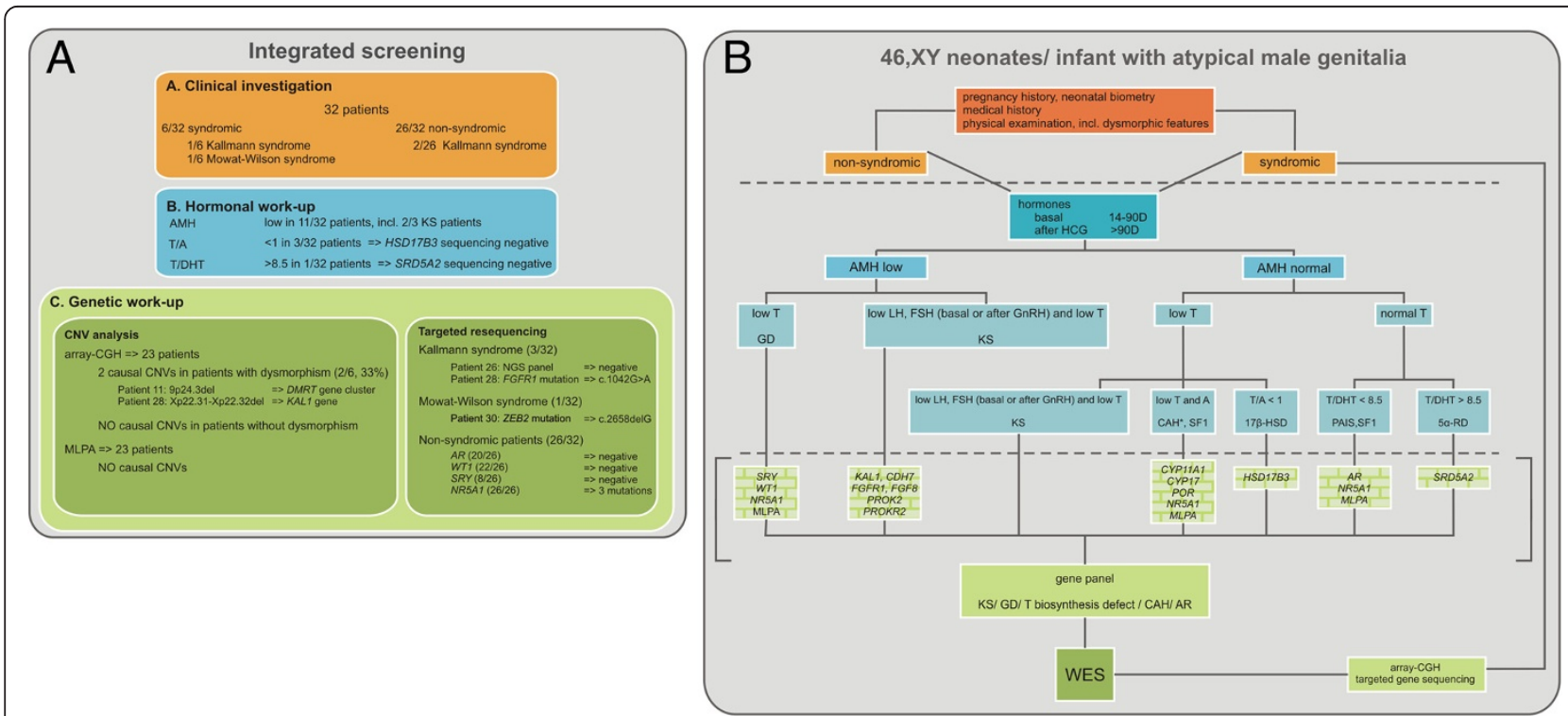

Figure 3 Overview of the integrated investigation approach. (A) Results in the 46,XY undervirilization cohort. Clinical and hormonal investigation was sufficient to suspect a diagnosis in 4/32 cases. For two Kallmann syndrome patients the diagnosis was genetically confirmed, as shown in the CNV analysis and targeted resequencing boxes. A ZEB2 mutation was identified in the Mowat-Wilson syndrome patient. Subsequently a genetic work-up was performed for the remaining patients, guided by hormonal results. Sequencing of HSD17B3 and SRD5A2 in patients with a possible testosterone biosynthesis disorder did not reveal mutations. Genetic screening consisting of array-CGH, DSD MLPA and sequential gene-bygene sequencing led to the identification of two causal CNVs (of which one KS, see above) and three novel NR5A1 mutations, respectively. (B) Suggested clinical algorithm for the investigation of $46, X Y$ male neonates or infants referred for atypical genitalia. Upper section (orange): clinical investigation, including pregnancy history, medical history and physical examination, enables categorization in cases with and without syndromic features. . Mid-section (blue): In all cases, clinical investigation should be followed by a hormonal work-up, which in turn can be suggestive of gonadal dysgenesis (GD), disorders of the steroid hormone biosynthesis pathway and/or rare forms of CAH (*:Only forms characterized by defective androgen production are implicated here), partial androgen receptor defects or KS. Insights in hormone levels can guide selection of target candidate genes. Lower section (green): After thorough evaluation of clinical and hormonal data, a decision can be made to sequence specific gene panels or to proceed to clinical whole exome sequencing to identify the underlying molecular cause and thereby support the clinical diagnosis. The boxes between brackets (with squared filling) represent single gene tests which can be replaced be the aforementioned gene panels In cases with syndromic features, array-CGH is still a recommended method to identify CNVs. 
and $\mathrm{T}$ values, which are generally considered more accurate than basal values during mini-puberty, had been obtained in only one of three patients with $\mathrm{T} / \mathrm{A}<1$. Another possible explanation might be the different detection methods used for the various androgens (Radioimmunoassay for A versus LC/MSMS for T). Simultaneous detection of A, T and DHT by LC/MSMS, as described recently, is expected to be more reliable but is not routinely available yet [28]. Low serum AMH has been reported previously in infants with KS [3,29], and has been attributed to a lack of FSH-driven stimulus [30,31].

In all cases in which serum AMH was below the agespecific reference values $(\mathrm{n}=10)$, sequencing of $S R Y$ was performed but revealed no mutations, confirming that $S R Y$ mutations are a relatively rare cause of $46, \mathrm{XY}$ partial gonadal dysgenesis in contrast to $46, \mathrm{XY}$ complete gonadal dysgenesis, where $S R Y$ mutations are thought to account for up to $15 \%$ of cases $[3,32]$.

\section{Genetic screening: targeted resequencing and copy number analysis}

Following a number of recent reports in which NR5A1, $A R$ and WT1 mutations and CNVs have been identified as the cause of isolated hypospadias and/or cryptorchidism [10,12,33-39], a standardized genetic screening protocol was applied to identify the underlying genetic cause of the observed atypical genital development in all cases where clinical and hormonal data did not suggest a specific diagnosis, irrespective of the EMS scores. The screening consisted of array-CGH, MLPA and SRY-specific FISH to screen for genomic rearrangements, and sequencing of the $A R, W T 1$ and NR5A1 genes.

\section{Array-CGH is a valuable diagnostic tool in $46, X Y$ undervirilization newborns with dysmorphic features and allowed the identification of two causal CNVs in our cohort} Array-CGH was used to screen for larger genomic rearrangements and led to the identification of two deletions with clinical significance, both found in syndromic patients. Patient $11(\mathrm{EMS}=3)$ presented with penoscrotal hypospadias and transposition. Besides these genital characteristics, this patient also showed macrocephaly, facial dysmorphism and developmental delay. Hormonal results revealed normal T levels, $\mathrm{AMH}$ was not available; array-CGH revealed a partial chromosome 9 deletion, encompassing the $D M R T$ gene cluster. These genes encode transcriptional regulators involved in sex development, and monosomy of the distal part of chromosome 9p, mostly DMRT1, has been associated with $46, \mathrm{XY}$ DSD in several cases [40,41]. Patient $28 \quad(\mathrm{EMS}=8)$ showed symptoms of KS. Other phenotypic characteristics included: X-linked ichthyosis, hypotonia, recurrent kidney stones and developmental delay. Liver function tests showed abnormal results, of hitherto unknown etiology. In this patient a part of the X-chromosome, including the genes KAL1 and NLGN4X, was deleted. KAL1 deletions or mutations are an established cause of Xlinked KS and can explain the genital phenotype seen in this patient [42]. NLGN4X, has been associated with $\mathrm{X}$ linked mental retardation and X-linked autism spectrum disorders [43], and might explain the observed developmental delay. Previously, a link between KS, ichthyosis and Xp deletions has been described by Bick et al. [44]. No evident association could be found between the identified deletion and the elevated liver enzymes and recurrent kidney stones. This deletion was inherited from the mother, who had mild mental delay but no symptoms of KS. This deletion is therefore characterized by incomplete penetrance.

In total, array-CGH revealed $10 \mathrm{CNVs}$ in 22 patients, seven of them were inherited from the mother; making their clinical relevance questionable. Array-CGH resulted in a definite genetic diagnosis in $2 / 22$ patients, (9\%). When only considering the syndromic cases, arrayCGH renders a diagnostic yield of $2 / 6$ patients (33\%). Although our series is small we can conclude that array-CGH is a valuable diagnostic tool in 46,XY DSD with associated dysmorphic features however larger patient groups should be investigated to make more definite conclusions. Because of the limited resolution of array-CGH, we performed MLPA to screen for deletions or duplications on the exon level for SOX9, NR5A1, WNT4 and NROB1. In total 23 patients were screened, however no additional $\mathrm{CNVs}$ were identified. Likewise, FISH analysis of SRY could not reveal any deletions. Although the mutation uptake of targeted CNV detection (MLPA) was limited in our cohort, it still remains an important addition to a genetic work-up of 46, XY undervirilized or 46,XY DSD patients. Different reports showed NR5A1 microdeletions as a cause of both 46,XY DSD and POF $[16,45]$

\section{We identified three novel NR5A1 mutations, one of them was present in an affected male with preserved fertility}

Recently Kohler et al. reported a WT1 mutation rate of $7.5 \%$ in children with severe hypospadias and Wang et al. identified $A R$ mutations in $6.6 \%$ of their patient cohort with isolated hypospadias and micropenis, indicating a role for both WT1 and $A R$ in minor forms of undervirilization [4,34]. Sanger sequencing of $A R$ and WT1 was done in respectively 20 and 22 patients of our cohort. In contrast to these series, no significant sequence changes in these genes were identified. The relatively high frequency in previous cohorts might be attributed to a selection bias. Therefore, we conclude that the incidence of mutations in AR and WT1 mutations is probably overestimated in patients with milder forms of undervirilization. On the other hand, NR5A1 was sequenced in 26 patients and revealed mutations in 
three of them (11.5\%). This is in line with other series, where mutations were identified in approximately $15 \%$ of patients. In our cohort, two frameshift mutations and one missense mutation were identified. The missense mutation, c.1109G $>\mathrm{A}$, found in patient $15(\mathrm{EMS}=3)$, targets an amino acid in the functionally important ligand binding domain (p.Cys370Trp) and is predicted to alter protein function (SIFT, Polyphen, MutationTaster). This mutation was also found in the patient's mother. In addition to causing 46,XY DSD, NR5A1 mutations are a known cause of premature ovarian failure (POF) [46]. The patient's mother had regular menses at the age of 30 , however she is at risk for developing POF. The first frameshift mutation (patient 3), c.253_254del induces a premature stop codon at position 85 (p.Ala85*). There were no additional family members available for segregation analysis. The second frameshift mutation (patient 6), c. 630_637del, also leads to a premature stop codon (p. Tyr211Profs 12*). This mutation was also present in the mother of the patient, a maternal aunt and the maternal grandfather. The aunt had recently been diagnosed with POF at the age of 35 years and underwent several in vitro fertilization (IVF) cycles, the patient's mother (age 39) declared to have regular menses. Interestingly, the grandfather had been treated for hypospadias as a child. Preserved fertility in males with NR5A1 mutations has only exceptionally been reported so far $[47,48]$. These findings support the extreme intrafamilial variability seen with NR5A1 mutations. At the moment the mechanism behind this phenotypic variability and incomplete penetrance resulting from NR5A1 mutations remains elusive; they likely result from the effects of multiple genetic variations (modifiers) and/or their interactions with environmental factors. Variable expressivity, reduced penetrance and even more complex inheritance patterns such as digenic models have been reported in other developmental conditions such as Kallmann syndrome and may be explained in part by the overall 'mutational load' in different genes playing a role in common signaling pathways [49-51].

\section{The integrated story: clinical, hormonal and genetic data}

Taken together, in spite of extensive clinical, hormonal and genetic screening, the molecular cause of 46,XY atypical male genital development could only be identified in seven out of 32 patients (21.8\%). When comparing the diagnostic success rate between patients with low $(<7, \mathrm{n}=17)$ or high $(\geq 7, \mathrm{n}=15)$ EMS scores, we identified the underlying molecular defect in respectively three and four patients, leading to a diagnostic success rate of respectively $17.6 \%$ and $26.5 \%$ for patients with low versus higher EMS scores, suggesting that the decision to perform a detailed diagnostic work-up in $46, \mathrm{XY}$ patients with atypical genitalia should not be based on the severity of the phenotype alone. Array-CGH revealed the causal CNV in two out of six syndromic patients, leading to a diagnostic yield of $33 \%$ in patients with additional phenotypic characteristics. When we included non-syndromic cases, the success rate drops to $9 \%$, indicating that array-CGH is still an appropriate diagnostic tool in syndromic forms of 46,XY DSD, but is less efficient in non-syndromic cases. Sequencing of $A R$, WT1 and $S R Y$ did not reveal any mutations. Besides the low diagnostic yield of this sequential sequencing approach, cost and time efficiency should be considered. Sanger sequencing has an average cost of $\$ 2400$ per million bases, whereas the emerging next generation sequencing technologies (NGS) are much cheaper. With the Illumina platform, there is only a $\$ 0.07$ sequencing cost per million bases (number based on Hiseq2000) [52]. The next step in the diagnostic work-up of $46, \mathrm{XY}$ boys wit atypical genitalia should be the implementation of targeted NGS panels covering clinically relevant genes with a known role in sex development and steroid biosynthesis pathways. A flexible and automated NGS workflow used for targeted resequencing of disease gene panels has been reported by us and allows parallel and cost-effective analysis of a sizeable number of genes in a clinical setting (De Leeneer et al. Human Mutation provisionally accepted). While this approach seems to be very useful in some heterogeneous disorders, their clinical utility in 46, $\mathrm{XY}$ DSD is debatable, since the known disease genes in these phenotypes only account for $20-40 \%$ of patients. Therefore we anticipate that whole exome sequencing (WES), which is increasingly put forward as a clinical diagnostic test in genetically heterogeneous disorders $[53,54]$, will gain importance in the diagnostic work-up of $46, \mathrm{XY}$ DSD, both in a clinical and research context. However, in cases where associated phenotypic characteristics or cases where clinical and hormonal data suggest a specific gene defect, it remains advisable to perform targeted resequencing of the specific disease gene(s).

\section{Conclusion}

In this study we examined a large consecutive cohort of undervirilized 46,XY neonates and infants. Following this protocol we were able to genetically diagnose $19 \%$ of non-syndromic patients and one third of the syndromic cases. There was no significant difference between the diagnostic success rate in patients with low EMS compared to higher EMS. In syndromic cases, array- $\mathrm{CGH}$ had a high diagnostic yield. Serial gene screening resulted in several novel NR5A1 mutations, although the overall diagnostic yield was rather low. Interestingly, we identified a novel NR5A1 mutation that was 
also present in a related male with preserved fertility, which has only exceptionally been reported. Given the low diagnostic yield of the sequential approach, parallel screening technologies such as targeted resequencing of clinically relevant disease genes and WES will be a preferred choice in future screening protocols. However, in cases where associated phenotypes are present, a more targeted approach remains the preferential strategy.

\section{Additional file}

Additional file 1: Table S1. Overview of the primer sequences for NR5Al (NM_004959.4), HSD 17B3 (NM_000197.1) and SRD5A2 (NM_000348.3).

\begin{abstract}
Abbreviations
A: Androstenedione; AMH: Anti-Müllerian hormone; Array-CGH: Arraycomparative genomic hybridization; CNV: Copy number variant; DSD: Disorders of sex development; DHT: Dihydrotestosterone; EMS: External masculinization score; FISH: Fluorescent in-situ hybridization; FSH: Follicle stimulating hormone; HoH: Hypogonadotropic hypogonadism; IVF: In vitro fertilization; KS: Kallmann syndrome; LH: Luteinizing hormone; MLPA: Multiplex ligation dependent probe amplification; MWS: Mowat-Wilson syndrome; POF: Premature ovarian failure; Rt-qPCR: Real-time quantitative PCR; SD: Standard deviation; UTR: Untranslated regions; WES: Whole exome sequencing.
\end{abstract}

\section{Competing interests}

The authors declare that they have no competing interests.

\section{Authors' contributions}

$\mathrm{MC}$ and $\mathrm{DB}$ were involved in writing of the manuscript. All other authors participated in revision of the draft. DB, EDB and BM conducted and interpreted the genetic tests. AD was responsible for data collection. $M C, P H$, $\mathrm{EVL}, \mathrm{BDC}$ and $\mathrm{BC}$ were involved in clinical diagnosis and management of patients included in this study. They provided clinical descriptions of the patients. Study design was set-up by MC. All authors read and approved the final manuscript.

\section{Acknowledgements}

We are most grateful to the patients, and their families, who participated in this study and to the referring clinicians who made this work possible. We thank Dr. Fiers for the execution of the biochemical tests.

DB is supported by a Special Research Fund (BOF) grant from the Ghent University. MC and EDB are supported by a Senior Clinical Investigator grant from the Flanders Research Foundation (FWO). WM was supported by a Clinical Fellowship from European Society of Pediatric Endocrinology (ESPE).

\section{Author details \\ ${ }^{1}$ Center for Medical Genetics, Ghent University Hospital and Ghent University, Ghent, Belgium. ${ }^{2}$ Department of Pediatric Endocrinology, Ghent University Hospital and Ghent University, Building 3K12D, De Pintelaan 185, 9000 Ghent, Belgium. ${ }^{3}$ Department of Pediatrics and Medical Genetics, Medical University of Varna, University Hospital "Sveta Marina", Varna, Bulgaria. ${ }^{4}$ Department of Pediatric Urology, Ghent University Hospital and Ghent University, Ghent, Belgium.}

Received: 12 September 2014 Accepted: 5 December 2014 Published online: 14 December 2014

\section{References}

1. Thyen U, Lanz K, Holterhus P-M, Hiort O: Epidemiology and initial management of ambiguous genitalia at birth in Germany. Horm Res 2006, 66:195-203.

2. Brain CE, Paediatric C, Creighton SM, Mushtaq I, Glasg F, Paed F, Clinical C, Barnicoat A: Holistic management of DSD. Best Pract Res Clin Endocrinol Metab 2010, 24:335-354.

3. Ono M, Harley VR: Disorders of sex development: new genes, new concepts. Nat Rev Endocrinol 2013, 9:79-91.
4. Köhler B, Biebermann H, Friedsam V, Gellermann J, Maier RF, Pohl M, Wieacker P, Hiort O, Grüters A, Krude H: Analysis of the Wilms' tumor suppressor gene (WT1) in patients $46, \mathrm{XY}$ disorders of sex development. J Clin Endocrinol Metab 2011, 96:E1131-E1136.

5. Ahmed SF: Prevalence of hypospadias and other genital anomalies among singleton births, 1988-1997, in Scotland. Arch Dis Child Fetal Neonatal Ed 2004, 89:149F-151F.

6. Toppari J, Virtanen HE, Main KM, Skakkebaek NE: Cryptorchidism and hypospadias as a sign of testicular dysgenesis syndrome (TDS): environmental connection. Birth Defects Res A Clin Mol Teratol 2010, 88:910-919.

7. Van der Zanden LFM, Van Rooij IALM, Feitz WFJ, Knight J, Donders ART, Renkema KY, Bongers EMHF, Vermeulen SHHM, Kiemeney LALM, Veltman JA, Arias-Vásquez A, Zhang X, Markljung E, Qiao L, Baskin LS, Nordenskjöld A, Roeleveld N, Franke B, Knoers NVAM: Common variants in DGKK are strongly associated with risk of hypospadias. Nat Genet 2011, 43:48-50.

8. Sharpe RM: Sperm counts and fertility in men: a rocky road ahead. Science \& Society Series on Sex and Science. EMBO Rep 2012, 13:398-403.

9. Hughes IA, Martin H, Jääskeläinen J: Genetic mechanisms of fetal male undermasculinization: a background to the role of endocrine disruptors. Environ Res 2006, 100:44-49.

10. Köhler B, Lin L, Mazen I, Cetindag C, Biebermann H, Akkurt I, Rossi R, Hiort $\mathrm{O}$, Grüters A, Achermann JC: The spectrum of phenotypes associated with mutations in steroidogenic factor 1 (SF-1, NR5A1, Ad4BP) includes severe penoscrotal hypospadias in $46, \mathrm{XY}$ males without adrenal insufficiency. Eur J Endocrinol 2009, 161:237-242.

11. Ferraz-de-Souza B, Lin L, Achermann JC: Steroidogenic factor-1 (SF-1, NR5A1) and human disease. Mol Cell Endocrinol 2011, 336:198-205.

12. Allali S, Muller J-B, Brauner R, Lourenço D, Boudjenah R, Karageorgou V, Trivin C, Lottmann H, Lortat-Jacob S, Nihoul-Fékété C, De Dreuzy O, McElreavey K, Bashamboo A: Mutation analysis of NR5A1 encoding steroidogenic factor 1 in 77 patients with $46, \mathrm{XY}$ disorders of sex development (DSD) including hypospadias. PLoS One 2011, 6:e24117.

13. Brauner R, Neve M, Allali S, Trivin C, Lottmann H, Bashamboo A, McElreavey $\mathrm{K}$ : Clinical, biological and genetic analysis of anorchia in 26 boys. PLoS One 2011, 6:e23292.

14. Köhler B, Schumacher V, I'Allemand D, Royer-Pokora B, Grüters A: Germline Wilms tumor suppressor gene (WT1) mutation leading to isolated genital malformation without Wilms tumor or nephropathy. J Pediatr 2001, 138:421-424.

15. Ledig S, Hiort O, Scherer G, Hoffmann M, Wolff G, Morlot S, Kuechler A, Wieacker P: Array-CGH analysis in patients with syndromic and nonsyndromic $\mathrm{XY}$ gonadal dysgenesis: evaluation of array $\mathrm{CGH}$ as diagnostic tool and search for new candidate loci. Hum Reprod 2010, 25:2637-2646.

16. Barbaro M, Cools M, Looijenga LHJ, Drop SLS, Wedell A: Partial deletion of the NR5A1 (SF1) gene detected by synthetic probe MLPA in a patient with XY gonadal disorder of sex development. Sex Dev 2011, 5:181-187.

17. Barbaro M, Cicognani A, Balsamo A, Löfgren A, Baldazzi L, Wedell A, Oscarson $\mathrm{M}$ : Gene dosage imbalances in patients with $46, \mathrm{XY}$ gonadal DSD detected by an in-house-designed synthetic probe set for multiplex ligationdependent probe amplification analysis. Clin Genet 2008, 73:453-464

18. Ahmed SF, Rodie M: Investigation and initial management of ambiguous genitalia. Best Pract Res Clin Endocrinol Metab 2010, 24:197-218.

19. Ahmed SF, Khwaja O, Hughes IA: The role of a clinical score in the assessment of ambiguous genitalia. BJU Int 2000, 85:120-124.

20. Menten B, Pattyn F, De Preter K, Robbrecht P, Michels E, Buysse K, Mortier G, De Paepe A, Van Vooren S, Vermeesch J, Moreau Y, De Moor B, Vermeulen S, Speleman F, Vandesompele J: arrayCGHbase: an analysis platform for comparative genomic hybridization microarrays. BMC Bioinformatics 2005, 6:124.

21. Twesten W, Holterhus P, Sippell WG, Morlot M, Schumacher H, Schenk BHO Clinical, endocrine, and molecular genetic findings in patients with 17 beta-hydroxysteroid dehydrogenase deficiency. Horm Res 2000, 53:26-31.

22. Walter KN, Kienzle FB, Frankenschmidt A, Hiort O, Wudy SA, van der WerfGrohmann N, Superti-Furga ASK: Difficulties in diagnosis and treatment of 5alpha-reductase type 2 deficiency in a newborn with 46, XY DSD. Horm Res Paediatr 2010, 74:67-71.

23. Miraoui H, Dwyer AA, Sykiotis GP, Plummer L, Chung W, Feng B, Beenken A, Clarke J, Pers TH, Dworzynski P, Keefe K, Niedziela M, Raivio T, Crowley WF, Seminara SB, Quinton R, Hughes VA, Kumanov P, Young J, Yialamas MA, Hall $J$ E, Van Vliet G, Chanoine J-P, Rubenstein J, Mohammadi M, Tsai P-S, Sidis Y, Lage K, Pitteloud N: Mutations in FGF17, IL17RD, DUSP6, SPRY4, and 
FLRT3 are identified in individuals with congenital hypogonadotropic hypogonadism. Am J Hum Genet 2013, 92:725-743.

24. Cox K, Bryce J, Jiang J, Rodie M, Sinnott R, Alkhawari M, Arlt W, Audi L, Balsamo A, Bertelloni S, Cools M, Darendeliler F, Drop S, Ellaithi M, Guran T, Hiort O, Holterhus P-M, Hughes I, Krone N, Lisa L, Morel Y, Soder O, Wieacker P, Ahmed SF: Novel associations in disorders of sex development: findings from the I-DSD Registry. I Clin Endocrinol Metab 2014, 99:E348-E355.

25. Grumbach MM: A window of opportunity: the diagnosis of gonadotropin deficiency in the male infant. J Clin Endocrinol Metab 2005, 90:3122-3127.

26. Boehmer A, Brinkmann A, Sandkuijl L, Halley D, Niermeijer M, Andersson S, De Jong F, Kayserili H, De Vroede M, Otten B, Rouwé C, Mendonca B, Rodrigues C, Bode H, De Ruiter P, Delemarre H, Drop S: 17betahydroxysteroid dehydrogenase-3 deficiency: diagnosis, phenotypic variability, population genetics, and worldwide distribution of ancient and de novo mutation*. J Clin Endocrinol Metab 1999, 84:4713-4721.

27. Baldinotti F, Majore S, Fogli A, Marrocco G, Ghirri P, Vuerich M, Tumini S, Boscherini B, Vetri M, Scommegna S, Rinaldi R, Simi P, Grammatico P: Molecular characterization of 6 unrelated Italian patients with 5alphareductase type 2 deficiency. J Androl 2008, 29:20-28.

28. Kulle AE, Riepe FG, Melchior D, Hiort O, Holterhus PM: A novel ultrapressure liquid chromatography tandem mass spectrometry method for the simultaneous determination of androstenedione, testosterone, and dihydrotestosterone in pediatric blood samples: age- and sex-specific reference data. J Clin Endocrinol Metab 2010, 95:2399-2409.

29. Vizeneux A, Hilfiger A, Bouligand J, Pouillot M, Brailly-Tabard S, Bashamboo A, McElreavey K, Brauner R: Congenital hypogonadotropic hypogonadism during childhood: presentation and genetic analyses in 46 boys. PLoS One 2013, 8:e77827

30. Lindhardt Johansen M, Hagen CP, Johannsen TH, Main KM, Picard J-Y, Jørgensen A, Rajpert-De Meyts E, Juul A: Anti-Müllerian Hormone and Its Clinical Use in Pediatrics with Special Emphasis on Disorders of Sex Development. International journal of endocrinology 2013:198698.

31. Young J, Chanson P, Salenave S, Noël M, Brailly S, O'Flaherty M, Schaison G, Rey R: Testicular anti-mullerian hormone secretion is stimulated by recombinant human FSH in patients with congenital hypogonadotropic hypogonadism. J Clin Endocrinol Metab 2005, 90:724-728.

32. Bashamboo A, McElreavey K: Gene mutations associated with anomalies of human gonad formation. Sex Dev 2013, 7:126-146.

33. Wang Y, Li Q, Xu J, Liu Q, Wang W, Lin Y, Ma F, Chen T, Li S, Shen Y: Mutation analysis of five candidate genes in Chinese patients with hypospadias. Eur J Hum Genet 2004, 12:706-712.

34. Alléra A, Herbst M, Griffin J, Wilson J, Schweikert H, McPhaul M: Mutations of the androgen receptor coding sequence are infrequent in patients with isolated hypospadias. J Clin Endocrinol Metab 1995, 80:2697-2699.

35. Hiort O, Klauber G, Cendron M, Sinnecker GH, Keim L, Schwinger E, Wolfe $\mathrm{HJ}$, Yandell DW: Molecular characterization of the androgen receptor gene in boys with hypospadias. Eur J Pediatr 1994, 153:317-321.

36. Sutherland RW, Wiener JS, Hicks JP, Marcelli M, Gonzales ET, Roth DR, Lamb $D J:$ Androgen receptor gene mutations are rarely associated with isolated penile hypospadias. J Urol 1996, 156(2 Pt 2):828-831.

37. Muroya K, Sasagawa I, Suzuki Y, Nakada T, Ishii T, Ogata T: Hypospadias and the androgen receptor gene: mutation screening and CAG repeat length analysis. Mol Hum Reprod 2001, 7:409-413.

38. Radpour R, Rezaee M, Tavasoly A, Solati S, Saleki A: Association of long polyglycine tracts (GGN repeats) in exon 1 of the androgen receptor gene with cryptorchidism and penile hypospadias in Iranian patients. J Androl 2007, 28:164-169.

39. Nordenskjöld A, Friedman E, Tapper-Persson M, Söderhäll C, Leviav A, Svensson $J$, Anvret M: Screening for mutations in candidate genes for hypospadias. Urol Res 1999, 27:49-55.

40. Onesimo R, Orteschi D, Scalzone M, Rossodivita A, Nanni L, Zannoni GF, Marrocco G, Battaglia D, Fundarò C, Neri G: Chromosome 9p deletion syndrome and sex reversal: novel findings and redefinition of the critically deleted regions. Am J Med Genet A 2012, 158A:2266-2271.

41. Quinonez SC, Park JM, Rabah R, Owens KM, Yashar BM, Glover TW, Keegan CE: 9P partial monosomy and disorders of Sex development: review and postulation of a pathogenetic mechanism. Am J Med Genet A 2013, 161A:1882-1896.

42. Beate K, Joseph N, Nicolas DR, Wolfram K: Genetics of isolated hypogonadotropic hypogonadism: role of $\mathrm{GnRH}$ receptor and other genes. Int J Endocrinol 2012, 2012:147893.
43. Laumonnier F, Bonnet-Brilhault F, Gomot M, Blanc R, David A, Moizard M-P, Raynaud M, Ronce N, Lemonnier E, Calvas P, Laudier B, Chelly J, Fryns J-P, Ropers H-H, Hamel BCJ, Andres C, Barthélémy C, Moraine C, Briault S: X-linked mental retardation and autism are associated with a mutation in the NLGN4 gene, a member of the neuroligin family. Am J Hum Genet 2004, 74:552-557.

44. Bick D, Curry CJ, McGill JR, Schorderet DF, Bux RC, Moore CM: Male infant with ichthyosis, Kallmann syndrome, chondrodysplasia punctata, and an Xp chromosome deletion. Am J Med Genet 1989, 33:100-107.

45. Harrison S, Campbell I, Keays M, Granberg C, Villanueva C, Tannin G, Zinn AR, Castrillon DH, Shaw CA, Stankiewicz P, Baker L: Screening and familial characterization of copy-number variations in NR5A1 in 46, XY disorders of Sex development and premature ovarian failure. Am J Med Genet 2013, 161:2487-2494.

46. Lourenco D, Brauner R, De Perdigo A, Weryha G, Muresan M, Boudjenah R, Guerra-Junoir G, Maciel-Guerra A, Achermann J, McElreavey K, Bashamboo A: Mutations in NR5A1 associated with ovarian insufficiency. N Engl J Med 2009, 360:1200-1210.

47. Philibert P, Polak M, Colmenares A, Lortat-Jacob S, Audran F, Poulat F, Sultan C: Predominant Sertoli cell deficiency in a 46,XY disorders of sex development patient with a new NR5A1/SF-1 mutation transmitted by his unaffected father. Fertil Steril 2011, 95:1788.e5-1788.e9.

48. Ciaccio M, Costanzo M, Guercio G, Dona V De, Marino R, Ramirez PC, Galeano J, Monica D, Esperanza W, Nora B, Rivarola MA, Belgorosky A: Preserved Fertility in a Patient with a 46, XY Disorder of Sex Development due to a New Heterozygous Mutation in the NR5A1/SF-1 Gene: Evidence of 46, XY and 46, XX Gonadal Dysgenesis Phenotype Variability in Multiple Members of an Affected Kindred. Horm Res Paediatr 2012:119-126.

49. Dodé C, Hardelin J-P: Kallmann syndrome. Eur J Hum Genet 2009, 17:139-146.

50. Quaynor SD, Kim H-G, Cappello EM, Williams T, Chorich LP, Bick DP, Sherins RJ, Layman LC: The prevalence of digenic mutations in patients with normosmic hypogonadotropic hypogonadism and Kallmann syndrome. Fertil Steril 2013, 96:1424-1430.

51. Costa-Barbosa FA, Balasubramanian R, Keefe KW, Shaw ND, Al-Tassan N Plummer L, Dwyer AA, Buck CL, Choi J-H, Seminara SB, Quinton R, Monies D, Meyer B, Hall JE, Pitteloud N, Crowley WF: Prioritizing genetic testing in patients with Kallmann syndrome using clinical phenotypes. J Clin Endocrinol Metab 2013, 98:E943-E953.

52. Liu L, Li Y, Li S, Hu N, He Y, Pong R, Lin D, Lu L, Law M: Comparison of next-generation sequencing systems. J Biomed Biotechnol 2012, 2012:251364.

53. Biesecker $L G$, Green RC: Diagnostic clinical genome and exome sequencing. N Engl J Med 2014, 370:2418-2425.

54. Yang Y, Muzny DM, Reid JG, Bainbridge MN, Willis A, Ward PA, Braxton A, Beuten J, Xia F, Niu Z, Hardison M, Person R, Bekheirnia MR, Leduc MS, Kirby A, Pham P, Scull J, Wang M, Ding Y, Plon SE, Lupski JR, Beaudet AL, Gibbs RA, Eng CM: Clinical whole-exome sequencing for the diagnosis of mendelian disorders. N Engl J Med 2013, 369:1502-1511.

\section{doi:10.1186/s13023-014-0209-2}

Cite this article as: Baetens et al:: Extensive clinical, hormonal and genetic screening in a large consecutive series of $46, \mathrm{XY}$ neonates and infants with atypical sexual development. Orphanet Journal of Rare Diseases 2014 9:209.

\section{Submit your next manuscript to BioMed Central and take full advantage of:}

- Convenient online submission

- Thorough peer review

- No space constraints or color figure charges

- Immediate publication on acceptance

- Inclusion in PubMed, CAS, Scopus and Google Scholar

- Research which is freely available for redistribution 